\title{
HOW EFFECTIVE ARE NATURE-BASED SOLUTIONS IN DIFFERENT ENVIRONMENTS?
}

\author{
ANA ASCENSO $^{1}$, CARLA GAMA $^{1}$, PETER ROEBELING $^{1,2}$ \& ANA ISABEL MIRANDA ${ }^{1}$ \\ ${ }^{1}$ CESAM - Centre for Environmental and Marine Studies, Department of Environment and Planning, \\ University of Aveiro, Portugal \\ ${ }^{2}$ Wageningen Economic Research, Wageningen University and Research, The Netherlands
}

\begin{abstract}
Air pollution is a major global concern in urban areas and it is considered the greatest environmental risk to health. Nature-based solutions (NBS) can help improve air quality and reduce the urban heat island effect. The impacts of urban vegetation on air quality and ambient temperature depend on many factors, such as vegetation type, location, pollutants, climate conditions and topography. Therefore, the implementation of NBS needs to be tailored for each city. Within the context of the H2020 UNaLab project, the main objective of this work is to assess the potential of NBS to improve air quality across three European cities with different climates: (i) Eindhoven, The Netherlands; (ii) Tampere, Finland; and (iii) Genova, Italy. The WRF-CHEM model was applied for the hottest week in a present climate reference year. The baseline case (without NBS) and two NBS scenarios were simulated for each city. These scenarios (green roofs and green parks) were implemented in the model by modifying the land-use type and the emissions of the model grid cells. According to the model results, the city that least benefited from NBS was Tampere with an average reduction of 5\% in surface temperature, and $1 \%$ in nitrogen dioxide $\left(\mathrm{NO}_{2}\right)$ and ozone $\left(\mathrm{O}_{3}\right)$ concentrations. Temperature-wise Genova and Eindhoven had similar results, approximately $6 \%$ reduction, while Genova showed the largest improvement in $\mathrm{NO}_{2}(12 \%)$. These results indicate that NBS are more effective in high temperature and high air pollution cities, such as Genova. Moreover, this study reinforces the importance of studying case-specific solutions, considering environmental characteristics and challenges.

Keywords: air quality, temperature, green roofs, green parks, modelling, urban areas.
\end{abstract}

\section{INTRODUCTION}

Urban areas need to achieve a balance between sustainable development and population growth. Climate change is making this balance even more difficult to attain. The increase in duration, intensity and frequency of extreme weather events will lead to more environmental, social and economic problems [1]. Among these environmental problems are air pollution and urban heating, which are causing high morbidity and mortality [2]. Air pollution is considered by the World Health Organization (WHO) to be the greatest environmental risk to health. Outdoor air pollution is responsible for 4.2 million worldwide deaths every year [3]. The most recent numbers show that $95 \%-98 \%$ of the European Union population was exposed to ozone $\left(\mathrm{O}_{3}\right)$ concentrations above the WHO guideline values set for the protection of human health [4].

Cities are more vulnerable to climate change and are also the most polluted areas. Urban areas need new and innovative approaches, such as nature-based solutions (NBS), to increase city resilience to climate change and promote better air quality [5]. The European Commission defines nature-based solutions as "solutions that are inspired and supported by nature, which are cost-effective, simultaneously provide environmental, social and economic benefits and help build resilience". NBS, such as street vegetation, green roofs 
and walls, can provide insulation and shade to buildings and therefore have the potential to reduce energy demands, by cutting back on heating and cooling needs, and indirectly reduce air pollutant emissions [6].

It is common to assess the impact of NBS on air quality by estimating the amount of pollutant removed through deposition [7]-[9]. However, there are also various studies assessing the impact of NBS on the urban air quality based on modelling approaches [6], [10]-[16], which allows the calculation of pollutants concentrations in the air integrating the effects of NBS on temperature and dispersion conditions. Most of the available air quality modelling studies concern microscale (in the range of metres) [10], [17], [18], but there are also several mesoscale (in the range of kilometres) modelling studies [6], [12], [13]. Therefore, the estimation of the NBS potential to improve air quality can change depending on the methodology used.

Moreover, it is known that NBS can reduce air pollution in different types of environments, and many ongoing projects are testing NBS impacts for different pollutant and climate conditions [19]. The implementation of NBS needs to be context-adapted, because the same solution can have a different impact depending on the specific characteristics of the urban area, like its land cover, population density and microclimate.

This work aims to assess how the impact of NBS can differ among cities with different characteristics, namely: (i) Eindhoven, The Netherlands; (ii) Tampere, Finland; and (iii) Genova, Italy. A mesoscale modelling system with a $1 \mathrm{~km} \times 1 \mathrm{~km}$ spatial resolution was applied for two types of NBS, green roofs (GR) and green parks (GP), to assess their impact on temperature and air quality. Nature-based solutions are a common strategy to reduce urban heat in the cities, moreover, temperature changes affect directly air pollutant concentration. The designed NBS scenarios were tailored to each city following a cocreation process with the stakeholders.

\section{CASE STUDIES}

Three European cities were chosen due to their track record in smart and citizen-driven solutions for sustainable development, growing urbanization and different climate zones: (i) Eindhoven, The Netherlands; (ii) Genova, Italy; and (iii) Tampere, Finland.

The City of Eindhoven is one of the five largest cities in The Netherlands with 230,000 inhabitants. Eindhoven has a temperate marine climate/oceanic climate (Köppen "Cfb") with slightly warmer summers and colder winters than the coastal parts of the Netherlands. The rapid urbanisation in recent years has led to the disappearance of significant blue zones. Currently, Eindhoven environmental challenges include flooding, urban heat stress and air pollution [20], which will worsen with climate change.

Genova is the largest city in the Liguria Region, with 607,000 inhabitants. Genova is characterised by a narrow coastal zone with hills and steep mountains in the backcountry. The city climate is subtropical and Mediterranean (Köppen "Cfa" and "Csa"). Due to extreme weather and a highly urbanised landscape, the city faces environmental challenges such as water management issues, heat stress, and water and air pollution [20]. With climate change, the city will have to face hazards like wildland fires, heatwaves, landslides and surface floods.

Tampere is the third-largest city in Finland and the largest inland centre in the Nordic countries. With 238,140 inhabitants and a population density of 448 per square kilometre, Tampere is one of the three most rapidly developing regions in-country and the centre of Finnish industry. Tampere has a borderline humid continental climate/subarctic climate (Köppen "Dfb" and "Dfc"). Twenty-four per cent of Tampere's surface area is water and $76 \%$ is land. Tampere's environmental challenges are related to flooding and stormwater 
management, as well as water pollution and reduced biodiversity [20], [21]. With climate change, the city will also face colder winters and warmer summers.

\section{METHODOLOGY}

This section describes the methodology for assessing the impacts of NBS on temperature and air quality, by introducing the WRF-CHEM model and the chosen simulation setup, and by characterising each NBS scenario.

\subsection{WRF-CHEM modelling system}

WRF-CHEM is the weather research and forecasting (WRF) model coupled with chemistry. It is a fully coupled mesoscale online model developed by Grell et al. [22] in which the air quality component is consistent with the meteorological component. Both components use the same transport scheme (vertical and horizontal coordinates), physics schemes for sub-grid scale transport and the same time step, and therefore interpolation in space and time is not required. The WRF dynamic solver integrates the compressible, nonhydrostatic Euler equations in flux form using variables that have conservation properties [23]. Detailed information on the model structure and its underlying equations are available in Skamarock et al. [24].

Three online-nested domains with increasing resolution at a downscaling ratio of five are used-with the coarser domain of $25 \mathrm{~km} \times 25 \mathrm{~km}$ horizontal resolution covering Europe and part of the North Atlantic Ocean, and the innermost domain of $1 \mathrm{~km} \times 1 \mathrm{~km}$ horizontal resolution covering the area containing the case-study region. The innermost domains have the following dimensions: Eindhoven, $51 \mathrm{~km} \times 41 \mathrm{~km}$; Genova, $41 \mathrm{~km} \times 36 \mathrm{~km}$ and Tampere, $46 \mathrm{~km} \times 36 \mathrm{~km}$. The model was forced by ERA-Interim data from the European Centre for Medium-Range Weather Forecasts (ECMWF) global analysis [25], with a horizontal resolution of $1^{\circ} \times 1^{\circ}$ and with a $6 \mathrm{~h}$ temporal resolution. Furthermore, WRFCHEM uses as inputs anthropogenic emissions [26], biogenic emissions (MEGAN model; [27]), initial and boundary conditions (MOZART model; [28]), and orography and land use (USGS 24 classes database). The required input data for WRF-CHEM were obtained from each city database as well as from open-source databases. WRF-CHEM output data are hourly three-dimensional fields that comprise a wide range of meteorological variables and pollutant concentrations, such as temperature $(\mathrm{T})$, nitrogen oxides $\left(\mathrm{NO}_{\mathrm{X}}\right)$ and ozone $\left(\mathrm{O}_{3}\right)$, the main variables assessed in this study. For a more detailed description of the modelling setup and its evaluation see Ascenso et al. [13].

\subsection{NBS scenario description}

The simulations were performed for the 7 hottest consecutive days of the representative year of the present/baseline scenario. The representative year is the one with the smallest climate anomaly regarding temperature and precipitation for the period 2012 to 2016 . The hottest week was simulated to balance the biggest NBS potential impact with less computational costs. The resulting simulation periods are: Eindhoven, 1-7 August 2013; Genova, 28 July-3 August 2013 and Tampere, 25-31 July 2012.

The tested NBS scenarios were defined with the help of the municipalities during cocreation workshops, in the scope of the UNALAB project. The NBS were implemented in the model by changing land use and emissions for the grid cells $(1 \mathrm{~km} \times 1 \mathrm{~km})$ that overlapped with the implementation areas. Note that by modifying the land use information, related variables, such as albedo, were also changed. For the GR scenarios the 
land use was altered to grass. For the GP scenarios, it was changed to shrubs, and the anthropogenic emissions were reduced to zero since the existing urban areas were converted into green parks. The main characteristics of the considered NBS scenarios are shown in Table 1, and their location and land use information in Fig. 1.

Table 1: Information and description of the tested NBS scenarios (the percentage of area with NBS is relative to the area inside the city boundaries). Legend: GR = green roofs; GP = green park.

\begin{tabular}{|c|c|c|c|c|}
\hline City & Sigla & Description & $\begin{array}{l}\text { NBS area } \\
\left(\% \mid \mathrm{km}^{2}\right)\end{array}$ & Ref \\
\hline \multirow[b]{2}{*}{ Eindhoven } & EIN_GR & GR in industrial areas & $6 \mid 5$ & Fig. 1(a) \\
\hline & EIN_GP & $\begin{array}{l}\text { GP in zones of the city lacking in green } \\
\text { space }\end{array}$ & $11 \mid 10$ & Fig. 1(b) \\
\hline \multirow{2}{*}{ Genova } & GEN_GR & $\begin{array}{l}\text { GR in the Lagaccio and S. Teodoro } \\
\text { neighborhoods }\end{array}$ & $0.8 \mid 2$ & Fig. 1(c) \\
\hline & GEN_GP & $\begin{array}{l}\text { GP on the margins of the Polcevera } \\
\text { river }\end{array}$ & $0.4 \mid 1$ & Fig. 1(d) \\
\hline Tampere & TAM_GR & GR in the city centre & $0.5 \mid 1$ & Fig. 1(e) \\
\hline
\end{tabular}

\section{GREEN ROOFS}
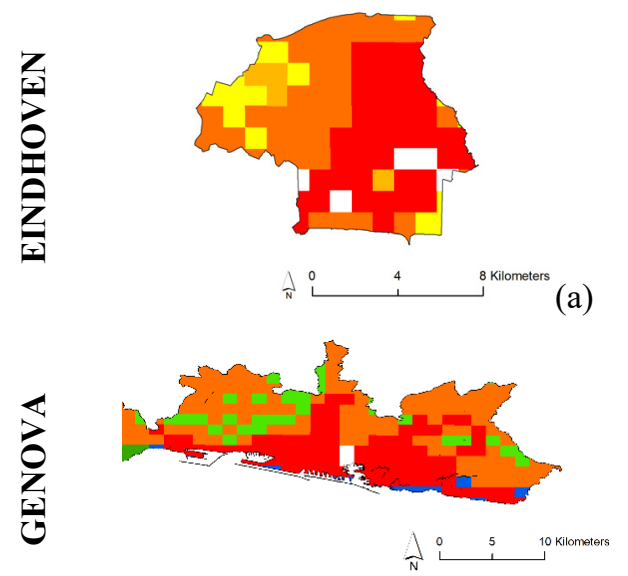

(c)

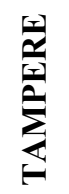

Legend

Land Use

Urban and Built-Up Land Dryland Cropland and Pasture

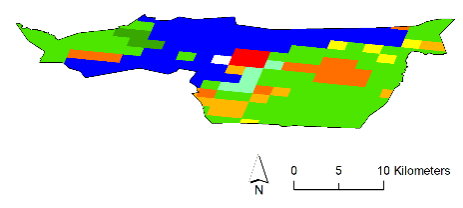

(e)
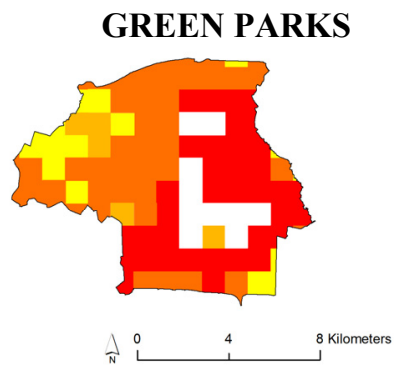

(b)

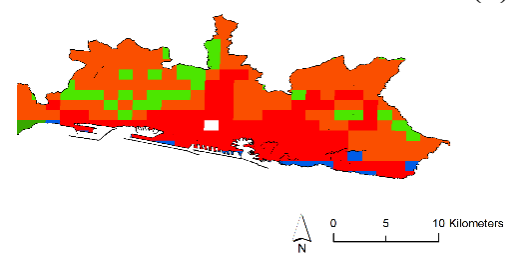

(d)

Figure 1: Location of NBS (white areas) and land use information, for each scenario and case study. 
Eindhoven scenarios stand out for having the largest area covered with NBS while being the smallest municipality. Whereas for Genova and Tampere the NBS scenarios have similar dimensions that correspond to a small percentage of municipality area. Tampere has already extensive green areas and considering the city environmental challenges, the municipality did not suggest a green park scenario. The case-specific solutions are a great way to compare the different cities' potential to benefit from NBS implementation. This assessment was done based on the model grid cells average, thus the results are normalized for $1 \mathrm{~km}^{2}$ of NBS implementation. This way it is possible to get a practical view of how effective nature-based solutions in different environments are.

\section{RESULTS AND DISCUSSION}

In this section the model results for $\mathrm{T}, \mathrm{NO}_{2}$ and $\mathrm{O}_{3}$ concentrations are analysed and discusses based on their hourly values, spatial averages and daily profiles. This assessment is based on values from the model cells where the NBS areas were implemented (see Fig. 1).

\subsection{Temperature}

During the study period, the average temperature for the baseline scenario was $21.9^{\circ} \mathrm{C}$ in Eindhoven, $24.9^{\circ} \mathrm{C}$ in Genova and $20.2^{\circ} \mathrm{C}$ in Tampere. Table 2 presents the average temperature values for the different cities and scenarios.

Table 2: Average temperature for the case study cities and the simulated scenarios. Legend: $\mathrm{GR}=$ green roofs; $\mathrm{GP}=$ green park.

\begin{tabular}{lccc}
\hline \multirow{2}{*}{ City } & \multicolumn{3}{c}{ Average temperature $\left({ }^{\circ} \mathrm{C}\right)$} \\
& Baseline & GR & GP \\
\hline Eindhoven & 21.9 & 21.6 & 21.5 \\
Genova & 24.9 & 24.1 & 24.6 \\
Tampere & 20.2 & 19.3 & \\
\hline
\end{tabular}

All the cities results indicate a temperature averaged reduction with the tested NBS.

However, the impact of NBS can vary greatly along the day. Fig. 2 shows the temperature daily profile for the baseline $\left({ }^{\circ} \mathrm{C}\right.$; black line), the NBS scenarios $\left({ }^{\circ} \mathrm{C}\right.$; dotted line) and the relative differences (\%; grey line).

The temperature reduction occurs mainly during night. This is explained by the change from the urban land use, with low albedo characteristics, which promotes the release of energy during the night, to green surfaces that accumulate less energy. This pattern is more noticeable for the Genova and Tampere NBS scenarios; these cities had the least amount of precipitation during the study period and received the highest amount of solar radiation, which promoted more evapotranspiration and thus a larger temperature reduction. Green surfaces increase the evapotranspiration rates enhancing the latent heat flux and reducing the sensible heat flux [29], which leads to a phenomenon called the "cool-island" effect [30].

The NBS implementation resulted in an increase in temperature at dawn, especially in Genova and Tampere. At these morning hours, the reduction in the sensible heat flux that occurs during the night shifts to an increase. 


\section{GREEN ROOFS}
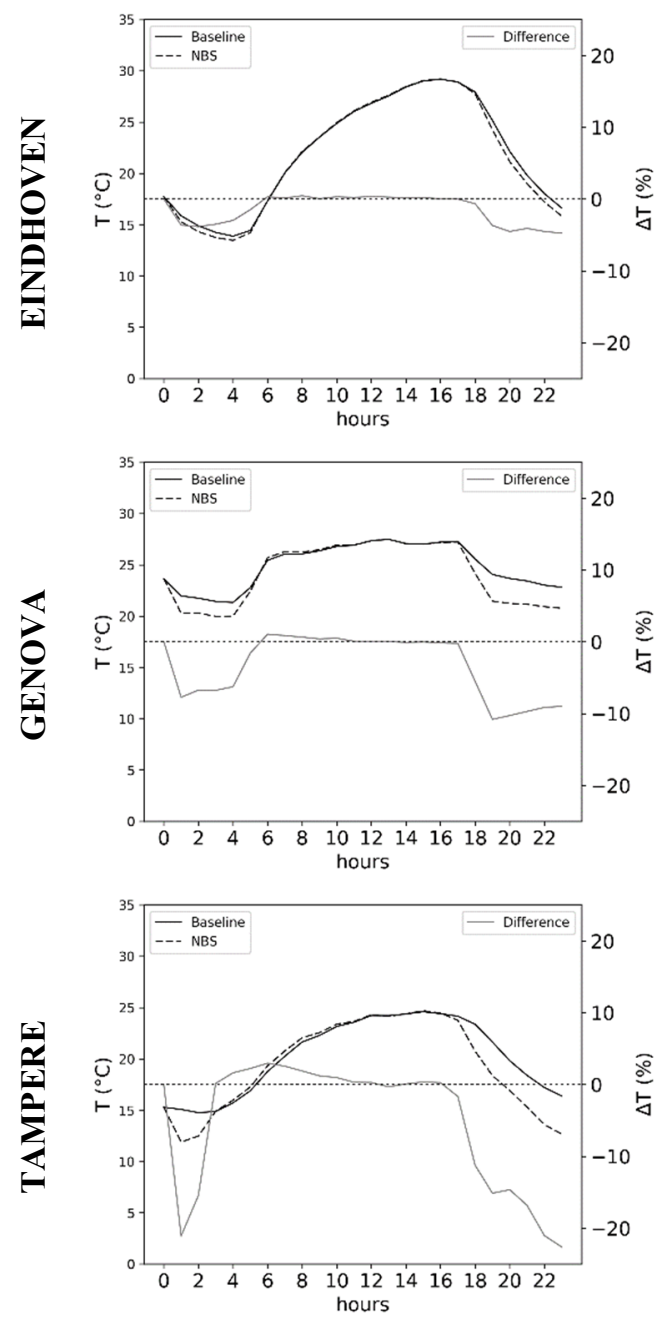

\section{GREEN PARKS}
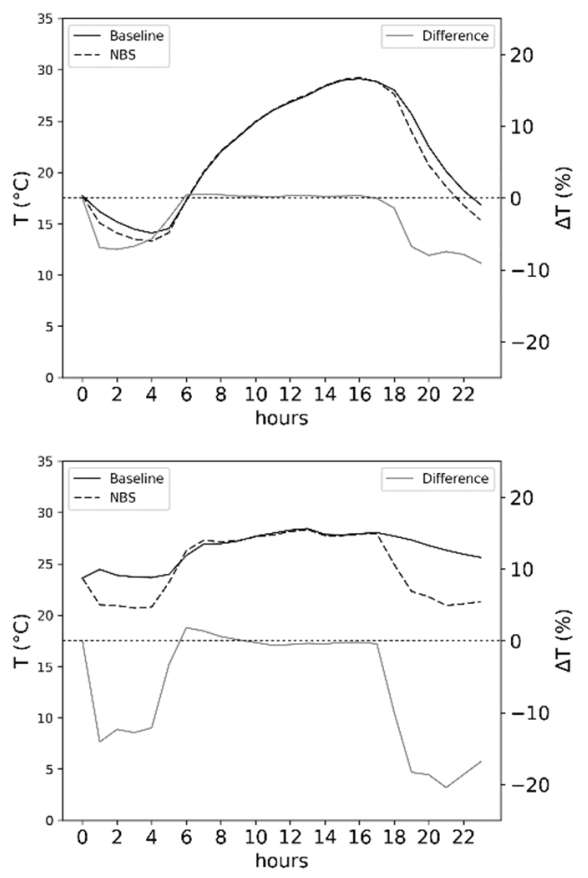

Figure 2: Temperature daily profile for baseline $\left({ }^{\circ} \mathrm{C}\right.$; black line), NBS scenarios $\left({ }^{\circ} \mathrm{C}\right.$; dotted line) and relative differences (\%; grey line), averaged through the NBS areas (UTC time).

\subsection{Air quality}

Hourly $\mathrm{NO}_{2}$ and $\mathrm{O}_{3}$ simulated values were treated and are here presented and discussed. Among the case studies, Genova has the highest baseline $\mathrm{NO}_{2}$ concentration values, twice exceeding the hourly limit value for the protection of human health, in one week. For Eindhoven and Tampere, $\mathrm{NO}_{2}$ concentrations are low and do not present a risk for human health. However, Eindhoven has the highest ozone levels, with an average of $82 \mu \mathrm{g} \cdot \mathrm{m}^{-3}$ maximum daily eight-hour mean and an hourly maximum of $108 \mu \mathrm{g} \cdot \mathrm{m}^{-3}$. Tampere is the case study with the best air quality. 
The overall NBS impacts on air quality are very small. The average difference between baseline and NBS scenarios is smaller than $1 \mu \mathrm{g} \cdot \mathrm{m}^{-3}$, except for GEN_GP which had an averaged $\mathrm{NO}_{2}$ reduction of $5 \mu \mathrm{g} \cdot \mathrm{m}^{-3}(-12 \%)$ and for GEN_GR with a reduction in $\mathrm{O}_{3}$ of 2 $\mu \mathrm{g} \cdot \mathrm{m}^{-3}(-3 \%)$. GP scenarios show the bigger impact in $\mathrm{NO}_{2}$ concentrations due to the change in anthropogenic emissions, which were considered zero over the area where the GP was implemented.

Fig. 3 shows the $\mathrm{NO}_{2}$ daily profile for the baseline $\left(\mu \mathrm{g} \cdot \mathrm{m}^{-3}\right.$; black line), the NBS scenarios $\left(\mu \mathrm{g} \cdot \mathrm{m}^{-3}\right.$; dotted line), and the relative differences ( $\%$; grey line).
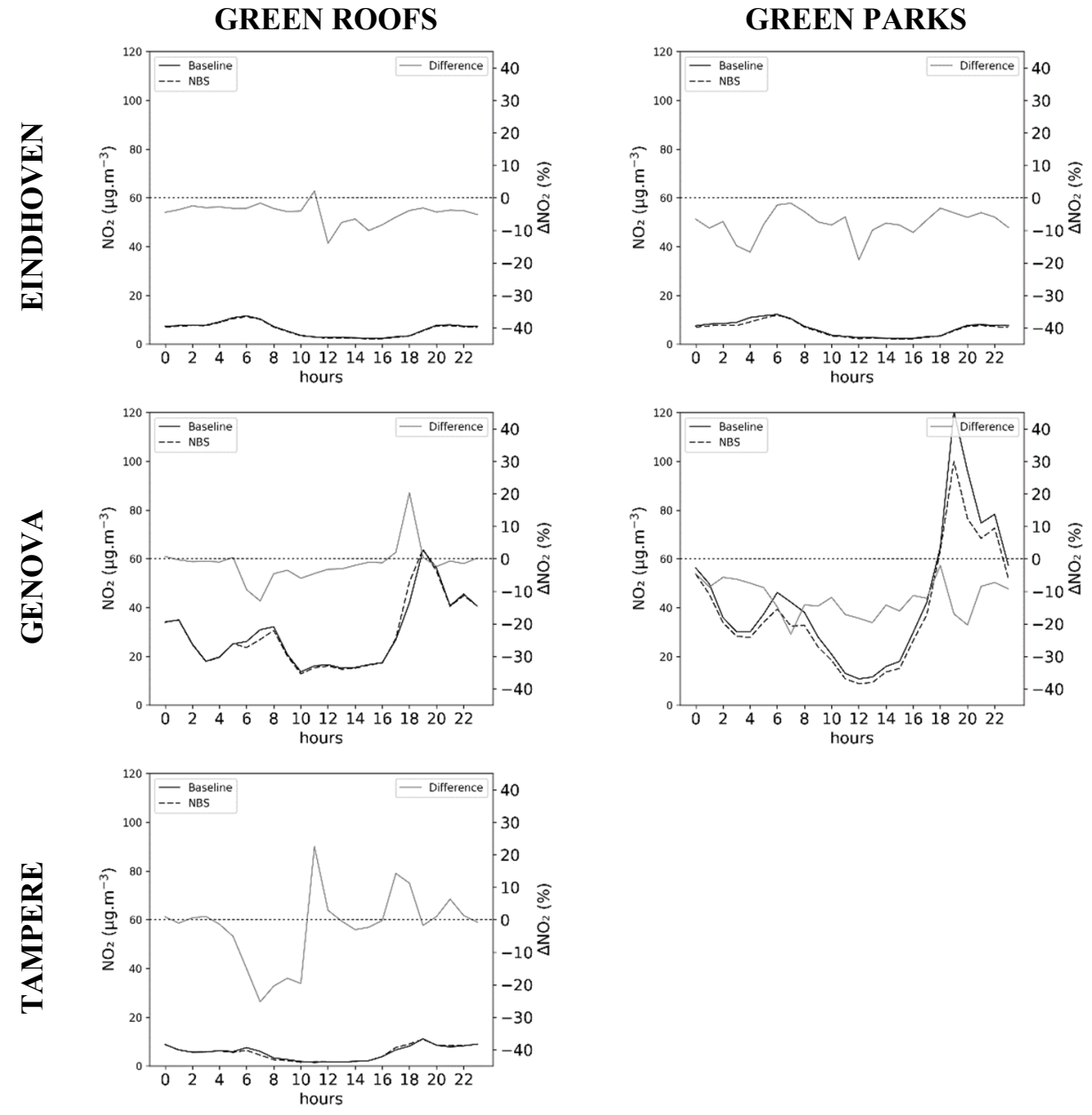

Figure 3: $\quad \mathrm{NO}_{2}$ daily profile for baseline $\left(\mu \mathrm{g} \cdot \mathrm{m}^{-3}\right.$; black line), NBS scenarios $\left(\mu \mathrm{g} \cdot \mathrm{m}^{-3}\right.$; dotted line) and relative differences (\%; grey line), averaged through the NBS areas (UTC time).

Fig. 3 shows a general reduction of $\mathrm{NO}_{2}$ concentration levels along the daily profile, in particular for the cities of Genova and Tampere. The impact for the city of Eindhoven is negligible. For the GR scenarios this reduction is larger at dawn, probably due to increase 
in temperature (seen in Fig. 2), which in turn promotes an increase in the boundary layer height, enabling air pollutants dispersion. Similarly, at the end of the day, the reduction in temperature led to an increase in $\mathrm{NO}_{2}$ concentration for the GEN_GR and TAM_GR scenarios.

When considering the GP impacts for Eindhoven and Genova, the reducing trend is also present, but residual for Eindhoven. On the other hand, the reduction of $\mathrm{NO}_{2}$ in Genova shows the effect of changing emissions along the day, with a larger reduction in the peak morning and afternoon hours; the impact of removing emissions was more relevant than the effect of NBS.
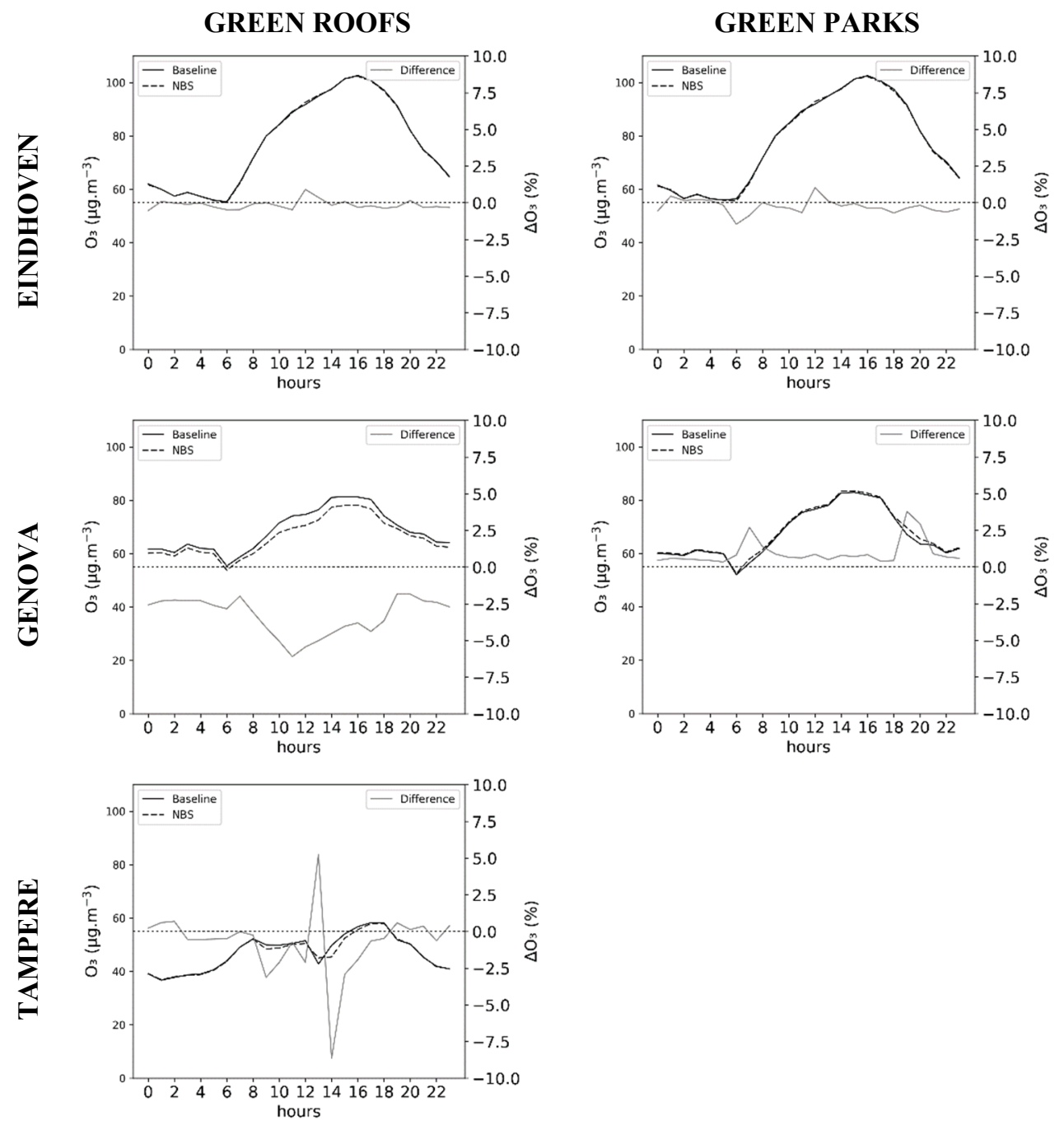

Figure 4: $\quad \mathrm{O}_{3}$ daily profile for baseline $\left(\mu \mathrm{g} \cdot \mathrm{m}^{-3}\right.$; black line), NBS scenarios $\left(\mu \mathrm{g} \cdot \mathrm{m}^{-3}\right.$; dotted line) and relative differences (\%; grey line), averaged through the NBS areas (UTC time). 
Fig. 4 shows the $\mathrm{O}_{3}$ daily profile for the baseline $\left(\mu \mathrm{g} \cdot \mathrm{m}^{-3}\right.$; black line), the NBS scenarios $\left(\mu \mathrm{g} \cdot \mathrm{m}^{-3}\right.$; dotted line) and the relative differences $(\%$; grey line).

$\mathrm{O}_{3}$ concentration was the indicator who least benefited from the NBS implementation. Once again, the impact for the city of Eindhoven, which is the city where ozone levels are the main air quality problem, is minimal. This can be explained by the very low baseline $\mathrm{NO}_{\mathrm{x}}$ values calculated by the model, resulting in small differences $\left(<1 \mu \mathrm{g} \cdot \mathrm{m}^{-3}\right)$, and that also originated a small impact in ozone concentrations as well.

The GEN_GP scenario resulted in an average increase of $1 \%$ in $\mathrm{O}_{3}$ concentrations. In urban areas where $\mathrm{NO}_{2}$ concentrations are high, such as Genova, $\mathrm{O}_{3}$ increases with the reduction of $\mathrm{NO}_{\mathrm{x}}$, because of the $\mathrm{NOx} / \mathrm{VOC}$ ratio in the atmosphere. Hence, the decrease in NO concentrations during the day, especially during dawn and nightfall (due to emission reduction), led to less ozone titration. The opposite effect can be seen in GEN_GR that showed the most ozone reduction with an average decrease of $3 \%\left(-2.4 \mu \mathrm{g} \cdot \mathrm{m}^{-3}\right)$. The NO concentrations increased during the day leading to more ozone removal through NO titration.

Tampere has the lowest $\mathrm{O}_{3}$ concentration of the three cities, and therefore the small differences can correspond to high percentages. The peaks in the averaged daily profile are related to high hourly differences reached on a particular day when the highest concentrations of the week occurred.

Table 3 contains a summary of the results based on the model cell with the highest impact along the study period.

Table 3: Summary of the NBS impact results for temperature and air quality for all cities; maximum average of temporal relative differences (\%), i.e. for the model cell with the highest impact along the study period.

\begin{tabular}{|c|c|c|c|c|c|c|c|c|c|c|c|c|}
\hline & \multicolumn{6}{|c|}{ GREEN ROOFS } & \multicolumn{6}{|c|}{ GREEN PARKS } \\
\hline & \multicolumn{2}{|r|}{$\mathrm{T}$} & \multicolumn{2}{|c|}{$\mathrm{NO}_{2}$} & \multicolumn{2}{|r|}{$\mathrm{O}_{3}$} & \multicolumn{2}{|r|}{$\mathrm{T}$} & \multicolumn{2}{|c|}{$\mathrm{NO}_{2}$} & \multicolumn{2}{|r|}{$\mathrm{O}_{3}$} \\
\hline & $\%$ & ${ }^{\circ} \mathrm{C}$ & $\%$ & $\mu \mathrm{g} \cdot \mathrm{m}^{-3}$ & $\%$ & $\mu \mathrm{g} \cdot \mathrm{m}^{-3}$ & $\%$ & ${ }^{\circ} \mathrm{C}$ & $\%$ & $\mu \mathrm{g} \cdot \mathrm{m}^{-3}$ & $\%$ & $\mu \mathrm{g} \cdot \mathrm{m}^{-3}$ \\
\hline Eindhoven & -6 & -1.27 & -8 & -0.47 & 0 & -0.28 & -6 & -1.27 & -11 & -0.7 & 0 & -0.33 \\
\hline Genova & -6 & -1.56 & -1 & -0.24 & -3 & -2.39 & -6 & -1.67 & -12 & -5.11 & 1 & 0.64 \\
\hline Tampere & -5 & -0.93 & -1 & -0.08 & -1 & -0.39 & & & & & & \\
\hline
\end{tabular}

Despite the different environmental characteristics, the relative differences show similar results between cities and scenarios. The impact of NBS on the temperature was approximately $5-6 \%$. For $\mathrm{NO}_{2}$ the GR scenario impact was the same for Genova and Tampere $(-1 \%)$ and was slightly higher $(-8 \%)$ for Eindhoven, where there was a constant reduction along the average daily profile. The GP scenario, for Eindhoven and Genova, resulted in a reduction of $11-12 \%$ (mainly due to emission reduction). Regarding $\mathrm{O}_{3}$, and despite the very small changes of the concentration values, the GP scenario had the least impact $0-1 \%$, and for GR the reduction ranged from $0-3 \%$.

Overall, Genova is the city that will benefit the most if these solutions are implemented. Genova is challenged with poor air quality and high temperatures, and the temperature at night does not decrease much. Thus, Genova has an interesting potential for NBS implementation.

\section{CONCLUSIONS}

The WRF-CHEM model was applied with high-resolution to quantify the impacts of green roofs and green parks on temperature and air quality $\left(\mathrm{NO}_{2}\right.$ and $\left.\mathrm{O}_{3}\right)$, for the hottest week in a 
reference year of the present climate on three distinct cities. The studied scenarios were proposed by the corresponding municipalities through a co-creation process. This research highlights the importance of considering the daily patterns of the NBS impact to enable more informed decisions and increase the effectiveness of these solutions.

Research results indicate that NBS can have a small impact on air quality and a bigger impact on temperature. NBS were more effective in areas with high temperatures and poor air quality. Thus, Genova is the city that will benefit the most if these solutions are implemented. However, the relative effects of NBS on temperature were very similar throughout the case studies and scenarios $(-5$ to $-6 \%)$ suggesting that, for this particular indicator, environmental conditions are not a major influence on NBS performance. Although the impact of NBS on air quality was small for Eindhoven and Tampere, these cities face other climate and environmental-related challenges and these solutions could still be beneficial.

\section{ACKNOWLEDGEMENTS}

The authors would like to thank the municipalities of Eindhoven, Genova and Tampere for providing information on the case studies. This work was supported by the UNaLab project (Grant Agreement No. 730,052, Topic: SCC-2-2016-2017: Smart Cities and Communities Nature-based solutions) and the GENESIS project (PTDC/GESURB/29444/2017). Thanks are also due for the financial support to the $\mathrm{PhD}$ grants of A. Ascenso (SFRH/BD/ 136875/2018) and CESAM (UIDB/50017/2020+UIDP/50017/2020), to FCT/MCTES through national funds, and the co-funding by the FEDER, within the PT2020 Partnership Agreement and Compete 2020.

\section{REFERENCES}

[1] IPCC, Climate Change 2014: Synthesis Report. Contribution of Working Groups I, II and III to the Fifth Assessment Report of the Intergovernmental Panel on Climate Change, eds R.K. Pachauri \& L.A. Meyer, IPCC: Geneva, Switzerland, 151 pp., 2014.

[2] Weilnhammer, V. et al., Extreme weather events in Europe and their health consequences: A systematic review. International Journal of Hygiene and Environmental Health, 233, 113688, 2021. DOI: 10.1016/j.ijheh.2021.113688.

[3] WHO, Ambient (outdoor) air pollution. https://www.who.int/news-room/factsheets/detail/ambient-(outdoor)-air-quality-and-health. Accessed on: 2 Aug. 2021.

[4] EEA, Air quality in Europe - 2020 report, No. 09/2020, 162 pp., 2020.

[5] Borrego, C. et al., Air quality, urban fluxes and cities resilience under climate change: A brief overview. International Journal of Environmental Impacts, 1(1), pp. 14-27, 2018. DOI: 10.2495/EI- 1-N1-14-27.

[6] Rafael, S., Correia, L.P., Ascenso, A., Augusto, B., Lopes, D. \& Miranda, A.I. Are green roofs the path to clean air and low carbon cities? Science of the Total Environment, 798, 149313, 2021. DOI: 10.1016/j.scitotenv.2021.149313.

[7] Nowak, D.J., Crane, D.E. \& Stevens J.C., Air pollution removal by urban trees and shrubs in the United States. Urban Forestry and Urban Greening, 4, pp. 115-123, 2006. DOI: 10.1016/j.ufug.2006.01.007.

[8] Tiwari, A. et al., Considerations for evaluating green infrastructure impacts in microscale and macroscale air pollution dispersion models. Science of the Total Environment, 672, pp. 410-426, 2019. DOI: 10.1016/j.scitotenv.2019.03.350. 
[9] Donateo, A. et al., An evaluation of the performance of a green panel in improving air quality, the case study in a street canyon in Modena, Italy. Atmospheric Environment, 247, 118189, 2021. DOI: 10.1016/j.atmosenv.2021.118189.

[10] Rodrigues, A. et al., Modelling the potential of green infrastructures to reduce the impact of climate change on air quality at microscale. Springer Proceedings in Complexity, pp. 147-152, 2020. DOI: 10.1007/978-3-030-22055-6_23.

[11] Augusto, B., Roebeling, P., Rafael, S., Ferreira J., Ascenso A. \& Bodilis, C., Short and medium- to long-term impacts of nature-based solutions on urban heat. Sustainable Cities and Society, 57, 102122, 2020. DOI: 10.1016/j.scs.2020.102122.

[12] Rafael, S., Augusto, B., Ascenso, A., Borrego, C. \& Miranda, A.I., Re-naturing cities: evaluating the effects on future air quality in the city of Porto. Atmospheric Environment, 222, 117123, 2019. DOI: 10.1016/j.atmosenv.2019.117123.

[13] Ascenso, A. et al., Impacts of nature-based solutions on the urban atmospheric environment: a case study for Eindhoven, The Netherlands. Urban Forestry and Urban Greening, 57, 126870, 2021. DOI: 10.1016/j.ufug.2020.126870.

[14] Fallmann, J., Forkel, R. \& Emeis, S., Secondary effects of urban heat island mitigation measures on air quality. Atmospheric Environment, 125, pp. 199-211, 2016. DOI: 10.1016/j.atmosenv.2019.117123.

[15] Arghavani, S., Malakooti, H. \& Bidokhti, A.A., Numerical evaluation of urban green space scenarios effects on gaseous air pollutants in Tehran metropolis based on WRF-Chem model. Atmospheric Environment, 214, 116832, 2019.

DOI: 10.1016/j.atmosenv.2019.116832.

[16] Tallis, M.J., Amorim, J.H., Calfapietra, C., Freer-Smith, P., Grimmond, S. \& Kotthaus, S., The impacts of green infrastructure on air quality and temperature: Planning. Handbook on Green Infrastructure: Planning, Design and Implementation, pp. 30-49, 2015. DOI: 10.4337/9781783474004.00008.

[17] Rafael, S., Vicente, B., Rodrigues, V., Miranda, A.I., Borrego, C. \& Lopes, M., Impacts of green infrastructures on aerodynamic flow and air quality in Porto's urban area. Atmospheric Environment, 190, pp. 317-330, 2018.

DOI: 10.1016/j.atmosenv.2018.07.044.

[18] Amorim, J.H., Rodrigues, V., Tavares, R., Valente, J. \& Borrego, C., CFD modelling of the aerodynamic effect of trees on urban air pollution dispersion. Science of the Total Environment, 461-462, pp. 541-551, 2013.

DOI: $10.1016 /$ j.scitotenv.2013.05.031.

[19] European Commission. Evaluating the Impact of Nature-based Solutions: A Handbook for Practitioners. Publications Office of the European Union: Luxembourg, 2021. DOI: 10.2777/244577.

[20] UNALAB, Our Cities R1 | UNaLab. https://unalab.eu/en/our-cities. Accessed on: 2 Aug. 2021.

[21] Municipality of Tampere, Information on Tampere, 2015. https://www.tampere.fi/en/ city-of-tampere/information-on-tampere.html. Accessed on: 2 Aug. 2021.

[22] Grell G.A. et al., Fully coupled 'online' chemistry within the WRF model. Atmospheric Environment, 39(37), pp. 6957-6975, 2005.

DOI: 10.1016/j.atmosenv.2005.04.027.

[23] Ooyama, K.V., A thermodynamic foundation for modeling the moist atmosphere. Journal of the Atmospheric Sciences, 47(21), pp. 2580-2593, 1990. DOI: 10.1175/1520-0469(1990)047\&lt;2580:ATFFMT>2.0.CO;2. 
[24] Skamarock, C. et al., A description of the advanced research WRF version 3 (No. NCAR/TN-475+STR). University Corporation for Atmospheric Research, 2008. DOI: $10.5065 / \mathrm{D} 68 \mathrm{~S} 4 \mathrm{MVH}$.

[25] Dee, D.P. et al., The ERA-Interim reanalysis: configuration and performance of the data assimilation system. Quarterly Journal of the Royal Meteorological Society, 137(656), pp. 553-597, 2011. DOI: 10.1002/qj.828.

[26] EMEP/CEIP, Emissions as used in EMEP models, 2015. www.ceip.at/webdabemission-database/emissions-as-used-in-emep-models. Accessed on: 2 Aug. 2021.

[27] Guenther, A., Karl, T., Harley, P., Wiedinmyer, C., Palmer, P.I. \& Geron, C., Estimates of global terrestrial isoprene emissions using MEGAN (Model of emissions of gases and aerosols from nature). Atmospheric Chemistry and Physics, 6(11), pp. 3181-3210, 2006. DOI: 10.5194/acpp-6-3181-2006.

[28] Emmons, L.K. et al., Description and evaluation of the model for ozone and related chemical tracers, version 4 (MOZART-4). Geoscientific Model Development, 3(1), pp. 43-67, 2010. DOI: 10.5194/gmd-3-43-2010.

[29] Rafael, S., Martins, H., Sá, E., Carvalho, D., Borrego, C. \& Lopes, M. Influence of urban resilience measures in the magnitude and behaviour of energy fluxes in the city of Porto (Portugal) under a climate change scenario. Science of the Total Environment, 566-567, pp. 1500-1510, 2016. DOI: 10.1016/j.scitotenv.2016.06.037.

[30] Santamouris, M., Cooling the cities: A review of reflective and green roof mitigation technologies to fight heat island and improve comfort in urban environments. Solar Energy, 103, pp. 682-703, 2014. DOI: 10.1016/j.solener.2012.07.003. 